\title{
The Crisis of Japanese Higher Education: Where Is the Problem?
}

Review of:

Shunya Yoshimi, 'Bunkeigakubuhaishi' no Shougeki [The Shock of Closing down University Humanities and Social Sciences Departments (my translation)], Shueisha, Tokyo, 2016.

Kazuaki Yoda ${ }^{1}$

${ }^{1}$ Waseda University, Tokyo, Japan

Correspondence: Kazuaki Yoda, Waseda University, Tokyo, Japan.

Received: August 22, 2017

Accepted: September 5, 2017

Online Published: September 19, 2017

doi:10.20849/aes.v2i3.177

URL: https://doi.org/10.20849/aes.v2i3.177

In this recently published book, Shunya Yoshimi discusses the controversy in Japanese higher education stirred by a request from the government sent in June 2015 to all national universities asking them to shut down their humanities and social sciences departments. Various media and intellectuals inside and outside of Japan immediately reacted and criticized the request of the government. The author carefully explains the details of how the controversy was stirred up. He also notes that although the news came as a shock because of inadequate treatments of media, is not abrupt but is part of the reform of national university system that begun in 1990s (such as loosening of the standards for university establishment and turning national universities into independent administrative entities), and further that the disparagement of humanities and social sciences has almost always existed since the birth of universities in Japan.

Yoshimi notes that except for the very early period of its history (late $19^{\text {th }}$ century) when education of bureaucrats was its main task, university education in Japan has focused on science and engineering fields. In the first half of the $20^{\text {th }}$ century, industrial competitiveness and technological development were its prime tasks because of the two World Wars. In the post-WWII period, this focus was maintained with a view to rebuilding the devastated nation and promoting economic growth. This focus continues through today in the name of strengthening the state's competitiveness in the global economy. The author claims that the government's request needs to be understood in this context and thus underneath the controversy lies the real issue concerning the whole concept of university in Japanese society. The crisis is not just about humanities and social sciences, but the raison d'etre of university itself in the society.

Hence the first half of the book discusses the crisis of humanities and social sciences and general disregard for their values followed by the author's attempt to defend them. In the latter half of the book, he brings up the crisis of university in contemporary Japanese society and argues for the urgent need for rebuilding the system noting some salient difficulties. Though this book received attention in Japan, few outside of Japan are aware of it because it was published only in Japanese. I hope this review can bring it to the attention of a wider audience.

The author first urges that we need to rethink the widely accepted view that, while science and engineering are useful, humanities and social sciences are largely useless. He urges us to revisit what we mean by the word "useful" and claims that there are two ways of usefulness: by contributing to the attainment of a given purpose (e.g. developing a new cure for a disease), and by creating new values and broadening perspectives in the absence of such a purpose (e.g. the value individual's rights). Science and engineering are said useful largely because they can demonstrate direct outcomes as their achievements. Meanwhile, it is difficult for humanities and social sciences to do the same because what they bring to us is not as obvious to us since it is not about achieving a given purpose. The distinction is coupled with a temporal difference. The former is the usefulness of the short time scale (several years to decades); the latter is that of the long time scale (some hundreds years). We need a long-term perspective in order to see the real value of humanities and social sciences.

At the same time, the author points to the crisis of Japanese higher education and calls for an extensive reform of it. His account indicates a critical feeling that seems to be lacking in many of the professors and administrators involved in governing universities. He names three waves that universities in Japan have been experiencing and thus are causing their crisis: low fertility, globalization and digitalization. The government has instituted reforms 
in order to overcome them, but the author reports how in fact they failed and caused the degradation of education quality.

His analysis of the current problematic conditions of Japanese higher education is particularly helpful as he promotes open discussion by revealing various conditions of esoteric university culture only people inside can figure. Nevertheless, his defense of humanities and social sciences seems oversimplified that distinguishes two ways of usefulness and claims that science and engineering are useful in the short time scale, while humanities and social sciences are in the long time scale. The author deserves much credit for making an attempt to rethink what it means to be useful and by doing so to defend the values of humanities and social sciences against the widely accepted view that they are useless. His discussion, however, is largely limited to the simplistic distinction between two senses of usefulness, and consequently the author's real position remains unclear. In claiming that the humanities and social sciences are useful, he suggests that they contribute to creating new values and broadening perspectives, i.e. promoting diversity. While at the same time, he repeatedly remarks that the mission of universities is to contribute to universality or universal value of humanity. This invites an obvious question: where does he locate the balancing point between universality and diversity? He notes that by universality he does not mean Christian sense of universality or a comparable one which, except within a particular social context, is not an option in modern and contemporary secular society. But what then does he mean by universality? Instead of a direct explanation, he mentions ideas such as sustainable global society and global excellence. This begs a further question: can the adjective universal be translated into global?

Moreover, throughout the book, the readers are left with the impression that the author is dragged in the economic value sticking to the word "useful." A notable example is that in mentioning major-minor system of liberal arts colleges, the author writes that philosophy is one of the most useful minors by reason that it contributes to innovations in technology, industry and business as if its chief value must be measured in the market. (Indeed, the adjective universal can be easily translated into global in the logic of market.) The readers are hence left with the confusion where the author's real position lies.

When university system was introduced in Japan in late $19^{\text {th }}$ century from Germany, academic disciplines in the West were already divided up and existed independently losing philosophy as the core or theology as the unifying principle. Universities in Japan begun with separate departments as it can be seen in the Japanese word "Kagaku," the common translation of the word sciences, that originally means miscellaneous disciplines. Unlike western universities, Japanese universities have no historical roots in scholasticism nor Neoplatonism both of which are based on Christianity and its universal value. The profundity of the author's claim of universality and universal value as the mission of universities is dubious without engaging in the question how Japanese society received the historical origin of western universities.

In addition, a crucial perspective is missing in the author's defense of humanities and social sciences. That is of the democratic citizenship education. Humanities and social sciences are valuable for the promotion of democratic society where all citizens must be committed to politics, the concern of the good of the public and the community as well as one's own. In the West, politics has been considered to be an indispensable component of a good life; while in Japan and probably more broadly in East Asia, democracy usually means universal suffrage and majority decision, and it does not necessarily involve all citizens' participation in political thinking. Can we really defend the significance of humanities and social sciences without affirming full democracy in Japanese society?

It is indispensable to address such fundamental questions in order to come up with a vision of what universities should be in contemporary Japanese society. The issue is urgent, but the question should not be degraded to how universities can merely survive the crisis. The author's defense falls short of such expectation. Nonetheless, the book is one of the few references that explains well the current critical conditions of university education in Japan with its historical background. All who are interested in Japanese higher education will benefit from it. I also recommend the book to those who are concerned about higher education in Asian countries, which, though each has its particular conditions, necessarily shares the issues around westernization.

\section{Copyrights}

Copyright for this article is retained by the author(s), with first publication rights granted to the journal.

This is an open-access article distributed under the terms and conditions of the Creative Commons Attribution license (http://creativecommons.org/licenses/by/4.0/). 